\section{Hypercholesterolemic diet induces hepatic steatosis and alterations in mRNA expression of NADPH oxidase in rat livers}

\author{
Dieta hipercolesterolemiante induz esteatose hepática e alterações \\ na expressão de mRNA da NADPH oxidase em fígados de ratos
}

Isabel Cristina Mallosto Emerich de Abreu', Joyce Ferreira da Costa Guerra ${ }^{2}$, Renata Rebeca Pereira 2,3 , Maísa Silva ${ }^{2}$, Wanderson Geraldo de Lima ${ }^{2,3}$, Marcelo Eustáquio Silva ${ }^{1,2}$, Maria Lúcia Pedrosa ${ }^{1,2,3}$

\begin{abstract}
Objective: This study aimed to determine whether a hypercholesterolemic diet induces hepatic steatosis, alterations in mRNA expression of NADPH oxidase subunits, and antioxidant defenses. Materials and methods: Fischer rats were divided into two groups of eight animals according to the treatment, control $(\mathrm{C})$ and hypercholesterolemic diet $(\mathrm{H})$. Those in group $\mathrm{C}$ were fed a standard diet (AIN-93M), and those of the group $\mathrm{H}$ were fed a hypercholesterolemic diet $(25 \%$ soybean oil and $1 \%$ cholesterol). Results: The hypercholesterolemic diet did not affect body weight, but resulted in the accumulation of lipids in the liver, increased serum activities of aminotransferases and cholesterol levels. Biomarker of lipid peroxidation (TBARS) and mRNA expression of NADPH oxidase subunits $\mathrm{p} 22^{\text {phox }}$ and $\mathrm{p} 47^{\text {phox }}$ were increased in the liver of animals in group $\mathrm{H}$. Besides, the activity and expression of antioxidant enzymes were altered. Conclusion: The results show increased mRNA expression of NADPH oxidase subunits and changes in antioxidant enzyme activities in diet-induced hepatic steatosis. Arq Bras Endocrinol Metab. 2014;58(3):251-9
\end{abstract}

\section{Keywords}

Antioxidant enzymes; hepatic steatosis; hypercholesterolemic diet; NADPH oxidase; non-alcoholic fatty liver disease; oxidative stress

\section{RESUMO}

Objetivo: Determinar se uma dieta hipercolesterolemiante induz esteatose hepática, alterações na expressão de mRNA da NADPH oxidase e nas defesas antioxidantes. Materiais e métodos: Ratas Fischer foram divididas em dois grupos de oito animais de acordo com o tratamento recebido, controle $(\mathrm{C})$ e hipercolesterolêmico $(\mathrm{H})$. Aquelas do grupo $\mathrm{C}$ foram alimentadas com dieta padrão (AIN-93M) e as do grupo $\mathrm{H}$ foram alimentadas com dieta hipercolesterolemiante (25\% de óleo de soja e $1 \%$ de colesterol). As dietas foram oferecidas por oito semanas. Resultados: $\mathrm{O}$ grupo $\mathrm{H}$ apresentou acúmulo de lipídios no fígado, aumento das atividades de ALT e AST e da concentração de colesterol no soro comparado ao grupo C. O marcador da peroxidação lipídica (TBARS) e os níveis de mRNA das subunidades $p 47^{\text {phox }}$ da NADPH-oxidase e p22 $2^{\text {phox }}$ foram aumentados no fígado de animais do grupo $\mathrm{H}$, além de alteração da atividade e expressão de enzimas antioxidantes. Conclusão: Os resultados mostram um aumento na expressão de subunidades da NADPH oxidase e alterações na atividade das enzimas antioxidantes na esteatose hepática induzida por dieta hipercolesterolemiante. Arq Bras Endocrinol Metab. 2014;58(3):251-9

\section{Descritores}

Enzimas antioxidantes; esteatose hepática; dieta hipercolesterolemiante; NADPH oxidase; doença hepática gordurosa não alcoólica; estresse oxidativo
School of Nutrition, Universidade Federal de Ouro Preto (UFOP), Campus Universitário, Morro do Cruzeiro, Ouro Preto, MG, Brazil ${ }^{2}$ Research Center in Biological Sciences, UFOP, Campus Universitário, Morro do Cruzeiro, Ouro Preto, MG, Brazil ${ }^{3}$ Department of Biological Sciences, UFOP, Campus Universitário, Morro do Cruzeiro, Ouro Preto, MG, Brazil

Correspondence to Maria Lúcia Pedrosa Instituto de Ciências Exatas e Biológicas, Campus Universitário, s/n, Morro do Cruzeiro

35400-000 - Ouro Preto, MG, Brazil Ipedrosa@nupeb.ufop.br

Received on Jun/6/2013 Accepted on Jan/24/2014 


\section{INTRODUCTION}

$\mathrm{N}$ on-alcoholic fatty liver disease (NAFLD) is the most common form of chronic liver disease. Nowadays, it is being considered a hepatic manifestation of metabolic syndrome (1-3).

NAFLD is a disease characterized by the accumulation of fat in the liver of patients without history of alcohol abuse (4). The spectrum of NAFLD includes simple fatty liver (when greater than $5 \%$ of the liver weight), and non-alcoholic steatohepatitis (NASH), showing steatosis and necroinflammation that may progress to liver cirrhosis, hepatocellular carcinoma, and advanced liver disease (2-6).

The molecular and cellular mechanisms underlying hepatic injury in NAFLD are not well defined. Several sources of evidence suggest that multiple mechanisms, including enhanced flow of free fatty acids and release of adipocytokines from the adipose tissue. In the liver, mitochondrial dysfunction, oxidative stress, and hepatocyte apoptosis are key contributors to hepatocellular injury. In addition, lipotoxic mediators and intracelullar signals activate Kupffer cells, which initiate and perpetuate the inflammatory response and development of fibrosis (7).

Oxidative stress occurs as a result of either excess generation of reactive oxygen species (ROS), and/or reduced antioxidant defenses. In the healthy liver, antioxidant systems such as catalase, superoxide dismutase, and glutathione peroxidase efficiently remove excess ROS to maintain normal cell homeostasis. On the other hand, one of the major sites of physiological ROS generation is NADPH oxidase (NOX) (8). NOX is an enzyme complex that generates ROS in response to a wide range of stimuli, and has been recognized as a key element of intracellular signaling of hepatic fibrogenesis (8).

A role for the NADPH oxidases in chronic liver diseases, such as fibrosis and viral hepatitis, related to chronic inflammation, has been proposed $(9,10)$. In the pathogenesis of alcoholic liver steatosis, there is an increase in NADPH oxidase activity and predominance of pro-oxidant agents, exceeding the capacity of the organic antioxidant defense (8). Under these circumstances, intracellular homeostasis in the redox status is interrupted and, sometimes, induces cell damage resulting in apoptosis or necrosis, potentially contributing to the devastating injury and dysfunction of liver tissue $(11,12)$.

Total body deficiency in $\mathrm{p} 47^{\text {phox }}$ subunit of NADPH oxidase complex protects mice from alcohol-in- duced liver steatosis (13). However, mice on a methionine-choline-deficient (MCD) diet develop NASH with similar pathology as the wild type, despite the lack of a functional NADPH oxidase enzyme (14). The role of this enzyme complex in the others animal models of NAFLD have not been investigated.

Because of the increasing prevalence of NAFLD, elucidating the mechanisms of oxidative stress-induced injury within the liver is vital for the understanding of the pathogenesis of this disease (15). Recent reports suggest that dietary cholesterol is a critical factor in the development of experimental steatohepatitis in animal models (16). Human studies also support the hypothesis that dietary cholesterol plays a role in the development of steatohepatitis. In an epidemiological study, it was reported that dietary cholesterol consumption was independently associated with the development of cirrhosis (17). In mice, the presence of triacylglycerol and cholesterol in the diet are needed for the development of both hepatic histological abnormalities of NASH and its associated metabolic abnormalities (16).

Our aims were to determine whether a hypercholesterolemic diet (25\% soy oil, $1 \%$ cholesterol) for eight weeks causes histologic hepatic alterations in female rats, and if this diet induces alterations in mRNA expression of NADPH oxidase and antioxidant defense enzymes, once oxidative stress is the implicated event contributing to the progression of liver steatosis to $\mathrm{NASH}$, and since the understanding of the mechanisms by which NAFLD and NASH are developed is extremely important for the development of therapeutic interventions.

\section{MATERIALS AND METHODS}

\section{Animals and experimental design}

Female Fischer rats weighing approximately 138 g were obtained from the Experimental Nutrition Laboratory of the Universidade Federal de Ouro Preto (UFOP). Animals were individually housed in wire-bottomed metabolic cages and kept in a room at controlled conditions $\left(24^{\circ} \mathrm{C}, 55 \%\right.$ humidity, 12-h light/dark cycles) with food and water ad libitum. The Ethics Committee on Animal Use of the UFOP approved all animal procedures. Rats were divided into two groups of eight animals each, and weighted. The first group served as the control $(\mathrm{C})$ and received a standard AIN-93M diet, 
and the second group $(\mathrm{H})$ received a hypercholesterolemic diet $(25 \%$ soybean oil and $1 \%$ cholesterol) ( $\mathrm{Ta}-$ ble 1). During the experiment, body weight and food intake were monitored. Food efficiency was calculated according to the following index: (body weight gain) $\mathrm{x}$ $(\text { food intake })^{-1}$.

Table 1. Composition of the experimental diets

\begin{tabular}{lcc}
\hline Nutrients & $\mathbf{C ~ ( g / k g )}$ & H (g/kg) \\
\hline Casein & 140.0 & 140.0 \\
Corn starch & 622.5 & 402.5 \\
Soybean oil & 40.0 & 250.0 \\
Cholesterol & 0.0 & 10.0 \\
Choline & 2.5 & 2.5 \\
Mineral mixture ${ }^{1}$ & 35.0 & 35.0 \\
Vitamin mixture ${ }^{2}$ & 10.0 & 10.0 \\
Cellulose & 50.0 & 50.0 \\
Saccharose & 100.0 & 100.0 \\
Energy content $(\mathrm{kcal} / \mathrm{kg})$ & 3810 & 4820 \\
\hline
\end{tabular}

$\mathrm{C}$ : group that received the standard diet; $\mathrm{H}$ : group that received the hypercholesterolemic diet. ${ }_{1}^{1}$ Salt mixture ( $\mathrm{g} / \mathrm{kg}$ of mixture): $\mathrm{NaCl}-139.3 / \mathrm{Kl}-0.79 / \mathrm{MgSO}_{4} 7 \mathrm{H} 2 \mathrm{O}-57.3 / \mathrm{CaCO}_{3}-381.4 /$ $\mathrm{MnSO}_{4} \cdot \mathrm{H}_{2} \mathrm{O}-4.01 / \mathrm{FeSO}_{4} \cdot 7 \mathrm{H}_{2} \mathrm{O}-0.548 / \mathrm{CuSO}_{4} \cdot 5 \mathrm{H} 2 \mathrm{O}-0.477 / \mathrm{COCl}_{2} \cdot 6 \mathrm{H}_{2} \mathrm{O}-0.023 / \mathrm{KH}_{2} \mathrm{PO}_{4}$ -389.0 .

2 Vitamin mixture (IU or g/kg of mixture): retinol acetate - $2000000 \mathrm{IU}$; cholecalciferol 200000 IU; p-aminobenzoic acid - 10.00; inositol - 10.00; niacin - 4.00; calcium pantothenate - 4.00; riboflavina - 0.80 ; thiamin $\mathrm{HCl}-0.50$; pyridoxine $\mathrm{HCl}$ - 0.50 ; folic acid - 0.20 ; biotin 0.04 ; vitamin B12 - 0.003 ; sucrose, quantity sufficient to $1 \mathrm{~kg}$; choline - 200.0; $\alpha$-tocopherol $-10,000 \mathrm{IU}$.

Conversion factors: protein $4 \mathrm{kcal} / \mathrm{g}$, fat $9 \mathrm{kcal} / \mathrm{g}$, sugar $4 \mathrm{kcal} / \mathrm{g}$.

\section{Sample preparation}

After eight weeks (56 days), rats were allowed a twelve-hour fast, anesthetized with isoflurane, and euthanized. To determine the levels of serum components, blood samples were collected in polypropylene tubes and centrifuged. Livers were removed, weighed, separated for histology, and the remainder immersed in liquid nitrogen, and immediately stored at $-80{ }^{\circ} \mathrm{C}$ for subsequent analysis. Abdominal and mesenteric fat were removed and weighed.

\section{Serum laboratory tests}

Serum activities of alanine aminotransferase (ALT), and aspartate aminotransferase (AST), cholesterol, triglyceride, high density lipoprotein (HDL), glucose, and total protein were measured using Labtest (Lagoa Santa, MG, Brazil) kits, and the measurements were performed according to the manufacturer's instructions. The batch and referencing number of each using kit were, respectively, 1004, 53-200; 1005, 52-200; 1013, 76-2/100; 1010, 87-2/100; 2001, 13-50; 2003, 84$1 / 500 ; 0003,99-250$.

\section{Hepatic histology}

Livers were removed at the end of the experiment and fixed in $4 \%$ buffered formalin. Subsequently, fixed lobes were transversely cut and processed in decreasing concentrations of alcohol, and embedded in paraffin. Paraffin sections of about $4-\mu \mathrm{m}$ were obtained in a semi-automatic microtome, mounted and stained by hematoxylin and eosin (H\&E) and Masson's trichrome. Photomicrographs were taken on a Leica DM5000 microscope coupled to a digital camera. Morphometric analyzes were performed using Image J Software. Lipid accumulation and hepatocytes with macrovesicular steatosis were counted in a total area of $1.5 \times 10^{6} \mu^{2}$ using paraffin sections stained with $H \& E$. The presence or absence of fibrosis was assessed by evaluation of paraffin sections stained Masson's trichrome in the same total tissue area.

\section{Real time quantitative RT-PCR assay}

Total RNA was isolated from the liver tissue of rats using the SV Total RNA Isolation System (Promega Corporation, Madison, USA) according to the manufacturer's instructions. cDNA was synthesized from $2 \mu \mathrm{g}$ of total RNA with random primers using the High-Capacity cDNA Reverse Transcription Kit (Applied Biosystems, Foster City, CA), following the manufacturer's recommendations. Real time PCR was performed with the Power SYBR ${ }^{\circledR}$ Green PCR Master Mix reagent (Applied Biosystems, Foster City, CA) in a final reaction volume of $12 \mu \mathrm{L}$; the reaction included $1 \mu \mathrm{L}$ of cDNA and $0.5 \mu \mathrm{L}$ of each primer (forward and reverse, $10 \mu \mathrm{M})$.

The primers used for amplifying transcripts of genes of interest were those related to NADPH oxidase subunits: gp9 $1^{\text {phox }}, \mathrm{p} 22^{\text {phox }}, \mathrm{p} 47^{\text {phox }}, \mathrm{p} 40^{\text {phox }}$ and $\mathrm{p} 67^{\text {phox }}$. The primers for CAT, Zn-superoxide dismutase (SOD), glutathione peroxidase (GPx), and gamma-glutamyl cysteine synthetase ( $\gamma$-GCS) were designed according to the nucleotide sequences published by Xiong and cols. (18). The primer for gene endogenous control 185 was used. The reactions were carried out under the following conditions: $50^{\circ} \mathrm{C}$ for $2 \mathrm{~min}, 95^{\circ} \mathrm{C}$ for $10 \mathrm{~min}$, and then 40 cycles of $95^{\circ} \mathrm{C}$ for $15 \mathrm{sec}$ (denaturation), and $60^{\circ} \mathrm{C}$ for $1 \mathrm{~min}$ (primer annealing and 
product extension). The specificity of the products obtained was confirmed by analysis of dissociation curves of the amplified product. The data obtained were analyzed using the comparative CT method. Target gene expression was determined relative to the expression of the endogenous $18 \mathrm{~S}$ gene. All analyses were performed in triplicate. It is important to note that all primers used were previously tested in other studies from our lab $(19,20)$.

\section{Antioxidant defenses and oxidative stress biomarker in liver homogenate}

Catalase (CAT) activity was determined according to Aebi (21), whose method is based on the enzymatic decomposition of $\mathrm{H}_{2} \mathrm{O}_{2}$ spectrophotometrically observed at $240 \mathrm{~nm}$ for $3 \mathrm{~min}$. Briefly, ten $\mu \mathrm{L}$ of homogenate supernatant was added to a cuvette containing 100 $\mathrm{mM}$ phosphate buffer ( $\mathrm{pH} 7.2$ ), and there action was initiated by the addition of $10 \mathrm{mM} \mathrm{H}_{2} \mathrm{O}_{2}$. Hydrogen peroxide decomposition was calculated using the molar absorption coefficient $39.4 \mathrm{M}^{-1} \mathrm{~cm}^{-1}$. The results were expressed as activity per milligram of protein. One unit of CAT is equivalent to the hydrolysis of $1 \mu \mathrm{mol}$ of $\mathrm{H}_{2} \mathrm{O}_{2}$ per min.

Superoxide dismutase (SOD) was assayed using Superoxide Dismutase Assay Kit (Cayman Chemical Company, $\mathrm{n}^{\circ}$ 706002). This essay utilizes a tetrazolium salt for the detection of superoxide radicals generated by xanthine oxidase and hypoxantine. One unit of SOD is defined as the amount of enzyme needed to cause $50 \%$ dismutation of the superoxide radical. Only $\mathrm{Cu} /$ Zn-SOD was measured.

The total glutathione content of liver homogenates was measured by the kit (CS0260) from Sigma (St. Louis, MO). The level of thiobarbituric acid reactive substances (TBARS) was estimated by the method of Buege and Aust (22). Liver homogenate supernatants were mixed with TCA $(28 \% \mathrm{w} / \mathrm{v}$ in $0.25 \mathrm{~N} \mathrm{HCl}), \mathrm{TBA}$ ( $1 \%$ in $0.25 \mathrm{M}$ acetic acid), and BHT (125 mM in ethanol), heated for $15 \mathrm{~min}$ at $95^{\circ} \mathrm{C}$ and then placed in an ice bath. The precipitated material was removed by centrifugation, and the absorbance of the sample at $\mathbf{5 3 5}$ $\mathrm{nm}$ was determined. TBARS concentration was calculated using the molar absorption coefficient of MDA $\left(154.000 \mathrm{M}^{-1} \mathrm{~cm}^{-1}\right)$.

Total protein content was determined according to the method described by Lowry and cols. (23) using bovine serum albumin (BSA) as the standard. This test was used only for correction of previous trials, such as catalase and TBARS.

\section{Statistical analysis}

Data were subjected to the Kolmogorov-Smirnov test for normality, expressed as mean \pm standard deviation (SD) in cases of normal distribution, and expressed as median in cases of non-parametric distribution. The Student $\mathrm{t}$ test was used for data with normal distributions and Mann-Whitney test was used for data with non-normal distributions. Differences were considered significant when $\mathrm{p} \leq 0.05$. All analyses were conducted using the software GraphPadPrism version 5.00 for Windows (San Diego, CA).

\section{RESULTS}

The hypercholesterolemic diet does not modify body weight

The two groups had similar baseline weight, as seen in table 2. At the final of the eight-week experiment, body weight did not change between the groups (Table 2). Although the animals of the control group had greater food intake, calorie intake (kcal) was the same in the two groups, demonstrating that food efficiency in the hypercholesterolemic group was better than in the control group $(\mathrm{p}=0.0003)$.

\section{The hypercholesterolemic diet causes lipid accumulation in the liver}

The hypercholesterolemic diet was not efficient in raising body weight, but caused lipid accumulation in the liver. There was no change in the weight of mesenteric and abdominal fats (Table 2).

\section{The hypercholesterolemic diet increases serum levels of liver enzymes and cholesterol}

The levels of liver enzymes AST and ALT were greater in $\mathrm{H}$ group compared with the $\mathrm{C}$ group, indicating that lipid accumulation was harmful to this organ (Table 2 and Figure 1). The hypercholesterolemic diet both increases serum levels of cholesterol and total proteins, and decreases the level of HDL, characterizing the disease hypercholesterolemia. The reduction in triglyceride levels is expected in this experimental model (Table 2 and Figure 1). 
Table 2. Body, liver, and fat weights and serum levels after eight weeks on the experimental diets (mean \pm SD)

\begin{tabular}{|c|c|c|c|}
\hline & C & H & Student $t$ test ( $p$ value) \\
\hline \multicolumn{4}{|l|}{ Weight } \\
\hline Initial weight (g) & $138.20 \pm 16.34$ & $138.30 \pm 11.35$ & 0.9904 \\
\hline Final weight (g) & $199.00 \pm 15.87$ & $205.8 \pm 13.96$ & 0.3494 \\
\hline Body weight gain (g) & $60.81 \pm 14.34$ & $67.51 \pm 11.11$ & 0.2800 \\
\hline Liver weight (g) & $5.25 \pm 0.55$ & $7.86 \pm 0.83$ & $<0.0001^{*}$ \\
\hline Abdominal fat weight (g) & $1.54 \pm 0.46$ & $1.63 \pm 0.49$ & 0.6905 \\
\hline Mesenteric fat weight (g) & $2.36 \pm 0.55$ & $2.56 \pm 0.56$ & 0.4629 \\
\hline \multicolumn{4}{|l|}{ Serum levels (fasting) } \\
\hline ALT (U/mL) & $14.24 \pm 7.01$ & $44.46 \pm 13.71$ & $<0.0001^{\star \star \star}$ \\
\hline AST (U/mL) & $38.03 \pm 11.14$ & $51.03 \pm 12.10$ & $0.0233^{*}$ \\
\hline Cholesterol (mmol/L) & $2.23 \pm 0.29$ & $3.25 \pm 1.25$ & $0.0389^{\star}$ \\
\hline Triglycerides (mmol/L) & $0.51 \pm 0.15$ & $0.37 \pm 0.06$ & $0.0126^{\star}$ \\
\hline $\mathrm{HDL}(\mathrm{mmol} / \mathrm{L})$ & $1.78 \pm 0.58$ & $0.26 \pm 0.10$ & $<0.0001^{\star \star \star}$ \\
\hline Glucose (mmol/L) & $5.89 \pm 0.92$ & $5.45 \pm 0.82$ & 0.3003 \\
\hline Total protein (g/dL) & $6.86 \pm 0.21$ & $7.36 \pm 0.39$ & $0.0050^{\star \star}$ \\
\hline
\end{tabular}

Data are expressed as mean \pm standard deviation. $(n=8)$. C: group that received the standard diet; H: group received the hypercholesterolemic diet. Statistical difference between means with ${ }^{\star} p \leq 0.05 ;{ }^{\star \star} p \leq 0.005 ;{ }^{* \star *} p \leq 0.0001$.

Table 3. Effects of the experimental diets on hepatic histology at eight weeks

\begin{tabular}{lcccc}
\hline & $\begin{array}{c}\text { Microvesicular } \\
\text { steatosis } \\
\mathbf{n}(\%)\end{array}$ & $\begin{array}{c}\text { Macrovesicular } \\
\text { steatosis } \\
\mathbf{n}(\%)\end{array}$ & $\begin{array}{c}\text { Inflammation } \\
\mathbf{n}(\%)\end{array}$ & $\begin{array}{c}\text { Fibrosis } \\
\mathbf{n}(\%)\end{array}$ \\
\hline $\mathrm{C}(\mathrm{n}=8)$ & $1(12.5)$ & $0(00)$ & $3(37.5)$ & $0(00)$ \\
$\mathrm{H}(\mathrm{n}=8)$ & $8(100)$ & $8(100)$ & $8(100)$ & $0(00)$ \\
\hline
\end{tabular}

C: group that received the standard diet; $\mathbf{H}$ : group that received the hypercholesterolemic diet.

\section{The experimental model is a good model to study simple steatosis}

According to table 3 we can notice that all animals in the $\mathrm{H}$ group had microvesicular and macrovesicular steatosis, demonstrating that a hypercholesterolemic diet during eight weeks induces steatosis, but does not influence either inflammatory infiltrate or fibrosis.

The liver sections showed the following histological features: the $\mathrm{C}$ group presented normal liver histology, and the $\mathrm{H}$ group presented steatosis with insignificant inflammatory infiltrate and absence of fibrosis, characterizing simple steatosis (Figure 2).

The mRNA expression of NADPH oxidase is altered in livers with simple steatosis

Quantitative PCR analysis showed increased expression of NADPH oxidase subunits $\mathrm{p} 22^{\mathrm{PHOX}}$ and $\mathrm{p} 47^{\mathrm{PHOX}}$ in hypercholesterolemic rats, compared with the $\mathrm{C}$ group (Figure 3).
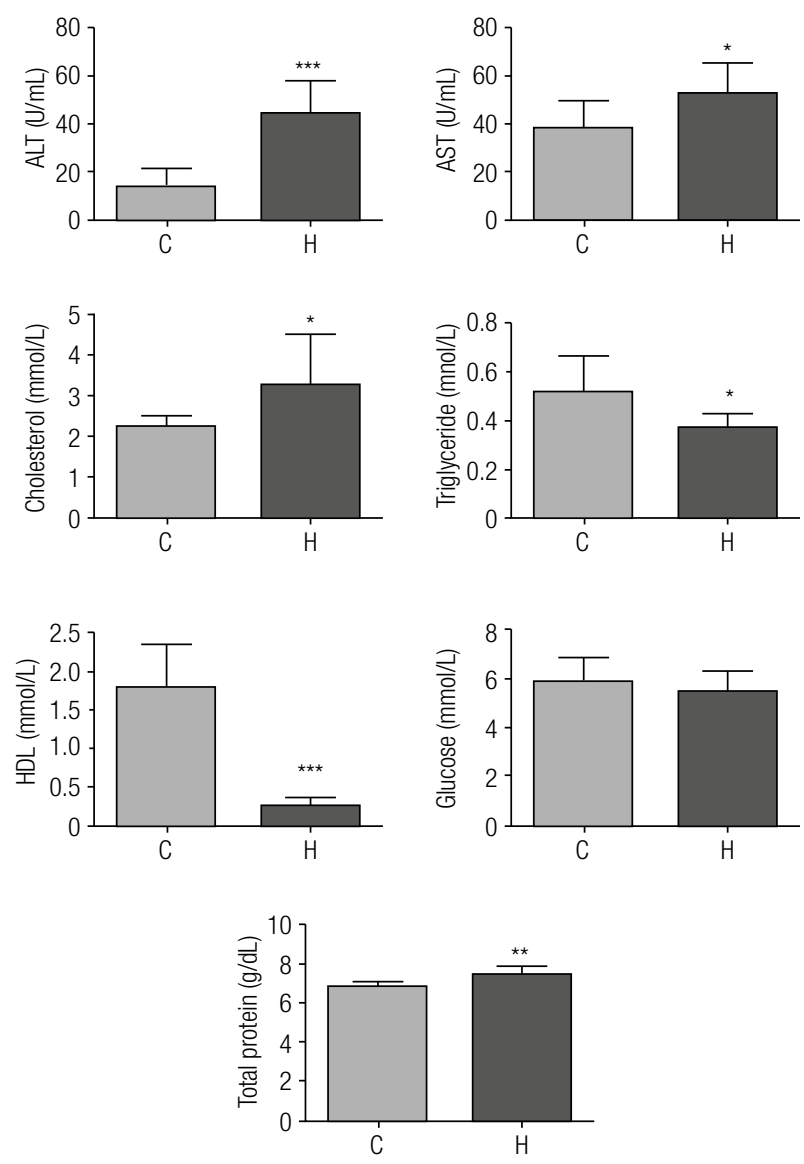

Figure 1. Metabolites and serum proteins (fast) after eight weeks of treatment with the experimental diets. C: group that received the standard diet; $\mathbf{H}$ : group received the hypercholesterolemic diet. For the statistical analysis, we used Student $t$ test. Data are expressed as means \pm standard deviations. $(n=8)$. Statistical differences between means with * $p \leq 0.05$, ${ }^{\star \star} p \leq 0.005,{ }^{* \star \star} p \leq 0.0001$. 
c
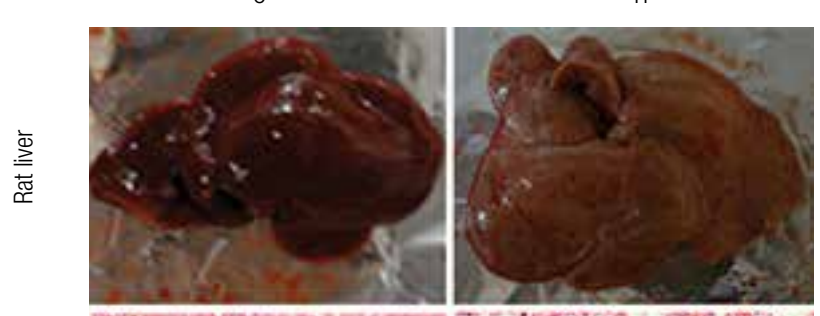

똥ㅁ
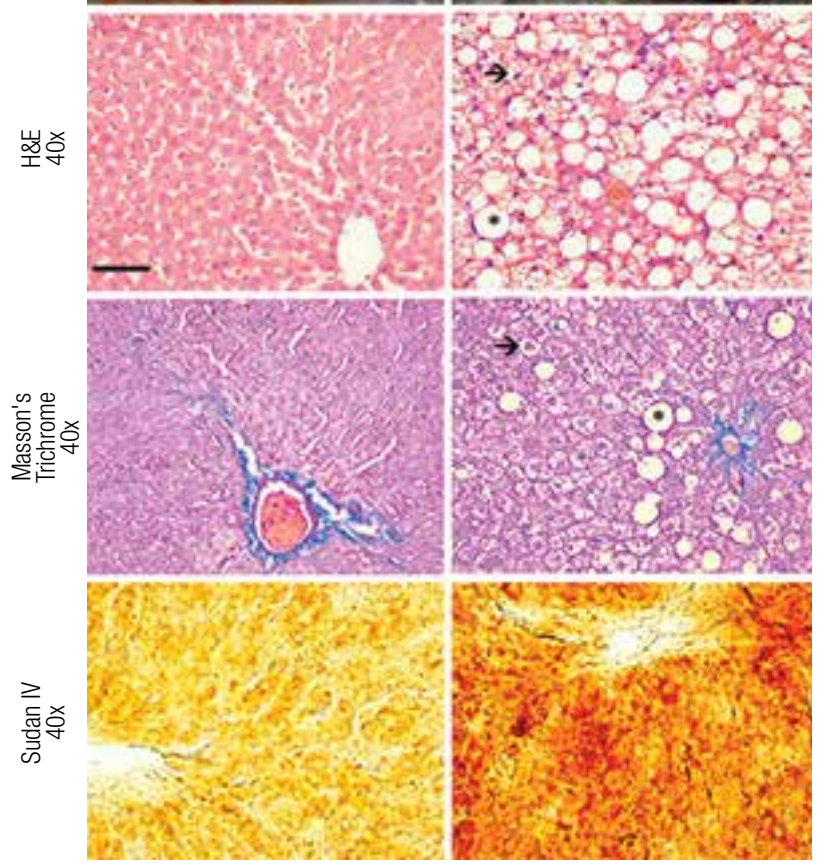

Figure 2. Photomicrographs representative of rat livers and sections of livers stained with $\mathrm{H} \& \mathrm{E}$ an Masson's trichrome and obtained after eight weeks in each of the experimental diets $(\mathbf{C})$, group that received standard diet; $(\mathbf{H})$, group that received the hypercholesterolemic diet. The arrows $(\rightarrow)$ indicate hepatocytes with microvesicular steatosis and asterisks $\left(^{*}\right)$ hepatocytes with macrovesicular steatosis. Bar $=50 \mu \mathrm{m}$.

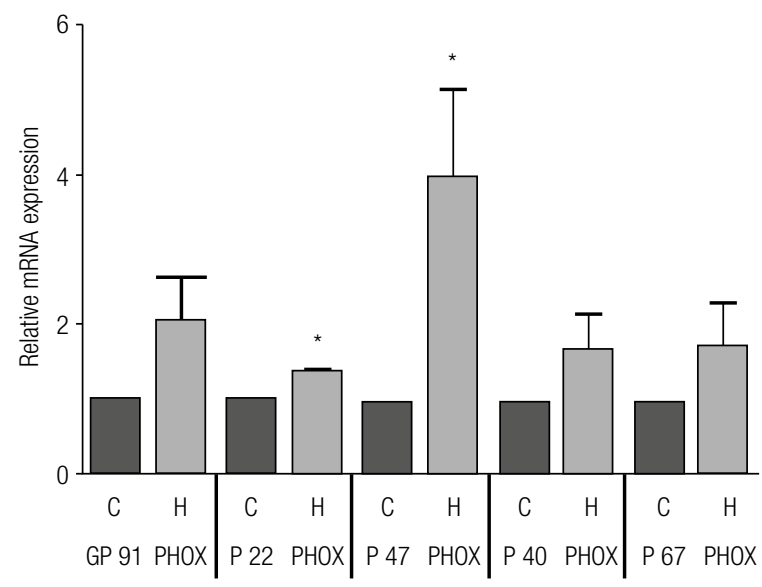

Figure 3. Liver mRNA expression of NADPH oxidase subunits in livers after eight weeks of treatment with the experimental diets. C: group that received the standard diet; $\mathbf{H : ~ g r o u p ~ t h a t ~ r e c e i v e d ~ t h e ~ h y p e r c h o l e s t e r o l e m i c ~}$ diet. For the statistical analysis, we used Student $t$ test. Data are expressed as mean \pm standard deviation. $(n=8)$. Statistical difference between means with * $P \leq 0.05$.
The activity and expression of antioxidant enzymes and TBARS are also altered by lipid accumulation in the liver

Catalase activity did not show significant differences between groups, but mRNA expression was decreased on $\mathrm{H}$ group. On the contrary, SOD presented reduced activity and mRNA expression was unchanged. The total hepatic glutathione content was 1.19-fold in the $\mathrm{H}$ group, and the mRNA expression decreased, compared with the control. TBARS levels are widely used as biomarkers of lipid peroxidation. Compared with control animals, the rats of the $\mathrm{H}$ group showed a 1.3 -fold increase in TBARS (Figures 4 and 5).
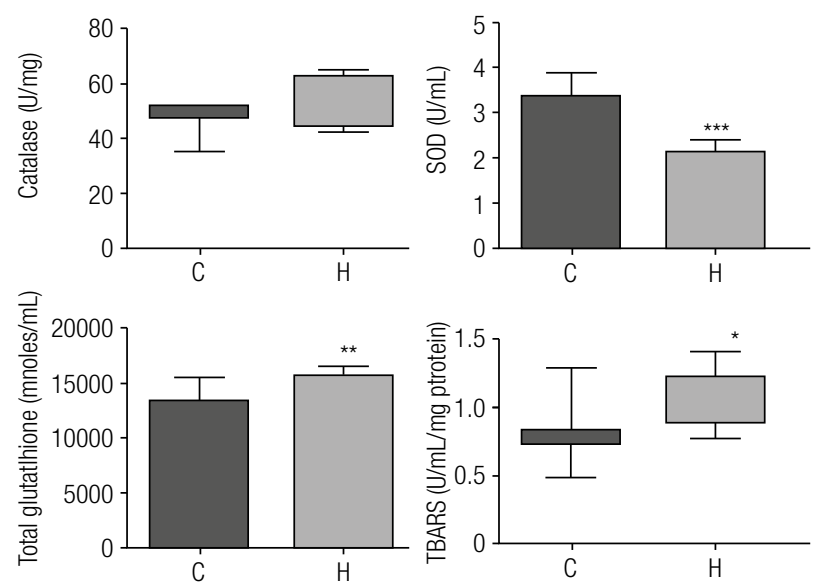

Figure 4. Antioxidant activity of enzymes and biomarkers of lipid peroxidation after eight weeks of treatment with the experimental diets. C: group that received standard diet; $\mathbf{H}$ : group that received the hypercholesterolemic diet. For the statistical analysis, we used Student $t$ test for SOD and total glutathione. Data are expressed as means \pm standard deviations. For the catalase and TBARS, we used the MannWhitney test. Data are expressed as medians $(n=8)$. Statistical difference between means with ${ }^{*} P \leq 0.05,{ }^{\star *} p \leq 0.005,{ }^{* \star *} p \leq 0.0001$.

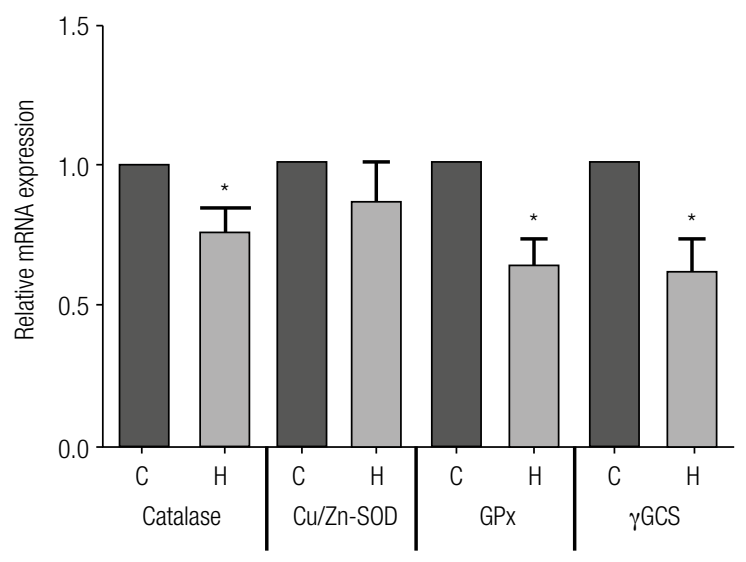

Figure 5. Liver mRNA expression of antioxidant enzymes after eight weeks of treatment with the experimental diets. C: group that received standard diet; H: group that received the hypercholesterolemic diet. For the statistical analysis, we used Student $t$ test. Data are expressed as means \pm standard deviations $(n=8)$. Statistical difference between means with * $P \leq 0.05$. 


\section{DISCUSSION}

Studies in animals have demonstrated strong associations between diet composition and balance and the development of fatty liver. Because of this, it has been postulated that dietary habits may promote NAFLD in humans. The mechanisms by which diet may play a role include modulation of hepatic triglyceride accumulation and regulation of the antioxidant activity, as well as changes in insulin sensitivity and postprandial triglyceride metabolism $(1,24,25)$. Both excessive carbohydrate intake (26) and excessive fat intake could play a role in increasing blood glucose, free fat acids, and insulin concentrations, independently or together $(1,6)$.

The diet containing $25 \%$ soybean oil and $1 \%$ cholesterol promoted hypercholesterolemia in rats and simple steatosis.

There is no single biochemical marker that can confirm a NAFLD diagnosis or distinguish between steatosis, NASH, and cirrhosis, but liver function tests abnormalities are common in patients with NAFLD, with elevations in ALT and AST usually no greater than four times the upper limit of normal $(3,27,28)$. Liver biopsy is the gold standard for the diagnosis of NAFLD, considering that it is the only method that can distinguish between simple steatosis, $\mathrm{NASH}$, and the degree of fibrosis $(29,30)$. Histologically, NASH is similar to alcohol-induced hepatitis, with the presence of macrovesicular steatosis, mixed inflammatory cell infiltration in the lobules, hepatocyte ballooning and necrosis, Mallory bodies, and perisinusoidal fibrosis or cirrhosis $(5,31)$.

As expected, our results indicated that the hypercholesterolemic diet caused liver damage, and increased oxidative stress and cholesterol levels in female rats. Liver injury was characterized by hepatomegaly and increased activities of AST and ALT enzymes. Hepatic histology indicates that animals fed the hypercholesterolemic diet presented lipid accumulation as shown by H\&E and Sudan IV staining. This can be viewed as macrovesicular steatosis, represented by large white vesicles and marked by the intensity of red color, indicating the presence of lipids, respectively. Masson's trichrome revealed no difference between the groups regarding the presence of fibrosis. Thus, it is evident that animals fed the hypercholesterolemic diet only showed steatosis, without progression to NASH and cirrhosis, proving that the hypercholesterolemic diet consisting of $25 \%$ soybean oil and $1 \%$ cholesterol administered for eight weeks was effective in inducing hepatic steatosis in Fischer rats.

During the development of NAFLD, there is an increased production of ROS, often leading to greater hepatic lipid peroxidation $(32,33)$. Our results showed that consumption of the hypercholesterolemic diet increased liver TBARS, indicating increased oxidative stress. It is known that oxidative stress can occur by increasing of pro-oxidant systems and/or by lowering antioxidant enzymes. Increased NADPH oxidase activity has been reported in animal models of NASH, in which dietary antioxidants or NADPH oxidase inhibitors ameliorated the progression of the disease (34-36). Thus, we decided investigate if there would be changes in gene expression of the subunits of this enzyme complex in this model.

The subunit $\mathrm{p} 47^{\mathrm{PHOX}}$ of NADPH oxidase is the main responsible for transporting the cytosolic complex from the cytosol to the membrane during oxidase activation. Before the cytosolic oxidase components can be transferred to the membrane, however, p47 $7^{\text {PHOX }}$ must be extensively phosphorylated (37). When $\mathrm{p} 47^{\mathrm{PHOX}}$ is phosphorylated, it binds to $\mathrm{p} 22^{\mathrm{PHOx}}$, an interaction that is probably responsible for activating the oxidase (38).

The p22 $2^{\text {PHOX }}$ functions as an integral subunit of the final electron transporter from NADPH to heme to molecular oxygen in generating superoxide anion (39). In this study, we found increased expression of $\mathrm{p} 47^{\mathrm{PHOX}}$ and $\mathrm{p} 22^{\mathrm{PHOX}}$ subunits of NADPH oxidase in the $\mathrm{H}$ group, thus indicating that this increase could be contributing to the activation of this enzyme complex, favoring the generation of ROS.

It is known that increase of ROS in cells can induce increase of antioxidant enzymes. Our results show that the livers of hypercholesterolemic rats was reduced in the mRNA expression of antioxidant enzymes, suggesting that the reduction of antioxidant enzyme activity could contribute to increased stress found in the livers of these rats. SOD activity appeared reduced; however, the same was not observed for catalase activity and glutathione concentration, suggesting an apparent contradiction. We suggest that, even with a possible reduction in the concentration of catalase that may not have been reflected in its activity due to its exceptional catalytic activity, a likely reduction in the concentration of GPx may compromise its role in eliminating peroxides, in spite of the increased concentration of total glutathione. 
Together, our data show a change in pro-oxidant/ antioxidant systems that resulted in increased TBARS. TBARS are by-products of oxidative stress that indicate lipid peroxidation. The production of 4-hydroxy2-nonenal (HNE) and malondialdehyde (MDA), types of TBARS, up-regulate liver fibrosis via activation of stellate cells and result in increased production of transforming growth factor-beta (3). Horoz and cols. (40) showed that patients with steatosis alone, and with NASH have higher levels of TBARS, corroborating our results.

The hypercholesterolemic diet consisting of $25 \%$ soybean oil and $1 \%$ cholesterol and administered for eight weeks was effective in inducing hepatic steatosis in rats, constituting a good model for the study of steatosis.

Definitively, hepatic steatosis should not be considered benign. In our experimental findings, we can prove that steatosis led to changes in mRNA expression and, consequently, an changed in the redox balance.

Understanding that steatosis alone may bring significant changes is an important step to define new strategies for the treatment of NAFLD in the future.

Acknowledgements: The authors declare that there is no potential conflict of interest. This study was supported by the Fundação de Amparo à Pesquisa de Minas Gerais (Fapemig, Minas Gerais, Brazil) and Conselho Nacional de Desenvolvimento Científico e Tecnológico ( $\mathrm{CNPq}$, Brazil). The authors would like to thank Nara Nunes Laje and Poliane Silva Maciel for their early contributions to the study, Jair Pastor Mota and Clodoaldo Pereira dos Santos for maintaining the animal facilities.

\section{REFERENCES}

1. Lazo M, Clark JM. The epidemiology of nonalcoholic fatty liver disease: a global perspective. Semin Liver Dis. 2008;28:339-50.

2. Ferré P, Foufelle F. Hepatic steatosis: a role for de novo lipogenesis and the transcription factor SREBP-1c. Diabetes Obes Metab. 2010;12:83-92.

3. Lewis JR, Mohanty SR. Nonalcoholic fatty liver disease: a review and update. Dig Dis Sci. 2010;55:560-78.

4. TakahashiY, Inui A, FujisawaT, Takikawa H, FukusatoT. Histopathological characteristics of non-alcoholic fatty liver disease in children: comparison with adult cases. Hepatol Res. 2011;41:1066-74.

5. Matteoni CA, Younossi ZM, Gramlich T, Boparai N, Liu YC, McCullough AJ. Nonalcoholic fatty liver disease: a spectrum of clinical and pathological severity. Gastroenterology. 1999;116:1413-9.

6. Finelli $\mathrm{C}$, Tarantino $\mathrm{G}$. Is there any consensus as to what diet or lifestyle approach is the right one for NAFLD patients? J Gastrointestin Liver Dis. 2012;21:293-302.

7. Ibrahim MA, Kelleni M, Geddawy A. Nonalcoholic fatty liver disease: current and potential therapies. Life Sciences. 2013;92:114-8.

8. Paik Y-H, Brenner DA. NADPH oxidase mediated oxidative stress in hepatic fibrogenesis. Korean J Hepatol. 2011;17:251-7.

9. Jiang JX, Venugopal S, Serizawa N, Chen X, Scott F, Li Y, et al. Reduced nicotinamide adenine dinucleotide phosphate oxidase 2 plays a key role in stellate cell activation and liver fibrogenesis in vivo. Gastroenterology. 2010;139:1375-84.

10. de Mochel NS, Seronello S, Wang SH, Ito C, Zheng JX, Liang TJ, et al. Hepatocyte NAD(P)H oxidases as an endogenous source of reactive oxygen species during hepatitis $C$ virus infection. Hepatology. 2010;52:47-59.

11. Evans JL, Goldfine ID, Maddux BA, Grodsky GM. Oxidative stress and stress-activated signaling pathways: a unifying hypothesis of type 2 diabetes. Endocr Rev. 2002;23:599-622.

12. Zhu W, Jia $Q$, Wang $Y$, Zhang $Y, X i a$ M. The anthocyanin cyanidin3-O- $\beta$-glucoside, a flavonoid, increases hepatic glutathione synthesis and protects hepatocytes against reactive oxygen species during hyperglycemia: Involvement of a cAMP-PKA-dependent signaling pathway. Free Radic Biol Med. 2012;52:314-27.

13. Levin I, Petrasek J, Szabo G. The presence of p47phox in liver parenchymal cells is a key mediator in the pathogenesis of alcoholic liver steatosis. Alcohol Clin Exp Res. 2012;36:1397-406.

14. dela Pena A, Leclercq IA, Williams J, Farrell GC. NADPH oxidase is not an essential mediator of oxidative stress or liver injury in murine MCD diet-induced steatohepatitis. J Hepatol. 2007;46:304-13.

15. Hardwick RN, Fisher CD, Canet MJ, Lake AD, Cherrington NJ. Diversity in antioxidant response enzymes in progressive stages of human nonalcoholic fatty liver disease. Drug Metab Dispos. 2010;38:2293-301.

16. Savard C, Tartaglione EV, Kuver R, Haigh WG, Farrell GC, Subramanian $\mathrm{S}$, et al. Synergistic interaction of dietary cholesterol and dietary fat in inducing experimental steatohepatitis. Hepatology. 2013;57:81-92.

17. Ioannou GN, Morrow OB, Connole ML, Lee SP. Association between dietary nutrient composition and the incidence of cirrhosis or liver cancer in the United States population. Hepatology. 2009;50:175-84.

18. Xiong Q1, Xie P, Li H, Hao L, Li G, Qiu T, et al. Acute effects of microcystins exposure on the transcription of antioxidant enzyme genes in three organs (liver, kidney, and testis) of male Wistar rats. J Biochem MolToxicol. 2010;24:361-7.

19. Guerra JF, Magalhães CL, Costa DC, Silva ME, Pedrosa ML. Dietary açai modulates ROS production by neutrophils and gene expression of liver antioxidant enzymes in rats. $\mathrm{J}$ Clin Biochem Nutr. 2011;49:188-94.

20. Rossoni Júnior JV, Araújo GR, Pádua Bda C, Magalhães $C L$, Chaves MM, Pedrosa ML, et al. Annatto extract and $\beta$-carotene enhances antioxidant status and regulate gene expression in neutrophils of diabetic rats. Free Radic Res. 2012;46:329-38.

21. Aebi H. Catalase in vitro. Methods Enzymol. 1984;105:121-6.

22. Buege JA, Aust SD. Microsomal lipid peroxidation. Methods Enzymol. 1978;52:302-10.

23. Lowry $\mathrm{OH}$, Rosebrough NJ, Farr $\mathrm{AL}$, Randall RJ. Protein measurement with the folin-phenol reagent. J Biol Chem. 1951;193:265-75.

24. Jenkins DJ, Josse AR, Labelle R, Marchie A, Augustin LS, Kendall CW. Nonalcoholic fatty liver, nonalcoholic steatohepatitis, ectopic fat, and the glycemic index. Am J Clin Nutr. 2006;84(1):3-4.

25. Cave M, Deaciuc I, Mendez C, Song Z, Joshi-Barve S, Barve S, et al. Nonalcoholic fatty liver disease: predisposing factors and the role of nutrition. J Nutr Biochem. 2007;18(3):184-95.

26. Solga S, Alkhuraishe AR, Clark JM, Torbenson M, Greenwald A, Diehl AM, et al. Dietary composition and nonalcoholic fatty liver disease. Dig Dis Sci. 2004;49(10):1578-83.

27. Pratt DS, Marshall M, Kaplan MM. Evaluation of abnormal liver-enzyme results in asymptomatic patients. N Engl J Med. 2000;342:1266-271.

28. Torres DM, Harrison SA. Diagnosis and therapy of nonalcoholic steatohepatitis. Gastroenterology. 2008;134:1682-98. 
29. Saadeh S, Younossi ZM, Remer EM, Gramlich T, Ong JP, Hurley M, et al. The utility of radiological imaging in nonalcoholic fatty liver disease. Gastroenterology. 2002;123:745-50.

30. Adams LA, Angulo P. Treatment of non-alcoholic fatty liver disease. Postgrad Med J. 2006;82:315-22.

31. Lee RG. Nonalcoholic steatohepatitis: tightening the morphological screws on a hepatic rambler. Hepatology. 1995;21:1742-3

32. Ludwig J, McGill DB, Lindor KD. Review: nonalcoholic steatohepatitis. J Gastroenterol Hepatol. 1997;12:398-403.

33. Morán-Ramos S, Avila-Nava A, Tovar AR, Pedraza-Chaverri J, López-Romero P, Torres N. Opuntia ficus indica (nopal) attenuates hepatic steatosis and oxidative stress in obese Zucker (fa/fa) rats. J Nutr. 2012;142(11):1956-63.

34. Carmiel-Haggai M, Cederbaum Al, Nieto N. A high-fat diet leads to the progression of non-alcoholic fatty liver disease in obese rats. FASEB J. 2005;19:136-8.
35. Lu LS, Wu CC, Hung LM, Chiang MT, Lin CT, Lin CW, et al. Apocynin alleviated hepatic oxidative burden and reduced liver injury in hypercholesterolaemia. Liver Int. 2007;27:529-37.

36. Sancho P, Martín-sanz P, Fabregat I. Reciprocal regulation of NADPH oxidases and the cyclooxygenase-2 pathway. Free Radical Bio Med. 2011;5:1789-98.

37. Babior BM. NADPH oxidase: an update. Blood. 1999;93:1464-76.

38. Babior BM. NADPH oxidase. Curr Opin Immunol. 2004;16:42-7.

39. Fukui T, Ishizaka N, Rajagopalan S, Laursen JB, Capers $Q$ 4th, Taylor WR, et al. p22phox mRNA expression and NADPH oxidase activity are increased in aortas from hypertensive rats. Circ Res. 1997;80:45-51.

40. Horoz M, Bolukbas C, Bolukbas FF, Sabuncu T, Aslan M, Sarifakiogullari $S$, et al. Measurement of the total antioxidant response using a novel automated method in subjects with nonalcoholic steatohep atitis. BMC Gastroenterol. 2005;5:35. 